\title{
PIOTR OSTAŃSKI
}

\section{Epizod o nagim młodzieńcu (Mk 14, 51-52) na tle biblijnej nauki o nagości}

Ewangelista Marek zawarł w zredagowanej przez siebie Ewangelii męki Pańskiej niewielki i pozornie mało znaczący epizod, który jednak wzbudza wśród komentatorów sporo kontrowersji. Chodzi o następujący tekst:

[...] wtedy opuścili Jezusa wszyscy i uciekli. A pewien młodzieniec szedt za Nim, odziany prześcieradtem na gotym ciele. Chcieli go chwycić, lecz on zostawit prześcieradto i uciekt »od nich«nago (Mk 14, 50-52).

Celem niniejszego opracowania jest studium nad przesłaniem tych wersetów w świetle biblijnej nauki o nagości.

\section{Terminologia}

\section{Slownictwo hebrajskie}

Określenia nagości w Biblii Hebrajskiej są derywatami dwóch trójspółgłoskowych rdzeni: ' $\hat{u} r$ oraz ' $r h$. Od pierwszego z nich ${ }^{1}$ pochodzą między innymi przymiotniki 'êrōm i 'ārôm, ważne z punktu widzenia problematyki niniejszego opracowania. 'Êrōm występuje w Piśmie Świętym dziesięć razy, a 'ārôm - piętnaście. Oba słowa posiadaja podobne znaczenie: „obnażony” albo „nagi” w sensie zarówno fizycznym, jak i przenośnym (symbolicznym). W tym ostatnim oznaczają: „cierpiący niedostatek”, „brak czegos”” albo „nędzę"2. Z rdzenia “ $\hat{u} r$

\footnotetext{
${ }^{1}$ Czasownik 'ûr występuje w Biblii tylko jeden raz, w Ha 3, 9 na oznaczenie „obnażonej” broni.

${ }^{2}$ Por. F. B r o w n [et al.]: A Hebrew and English lexicon of the Old Testament. Oxford [br.] s. $735-736$.
} 
pochodzi też hebrajski rzeczownik ma ăreh („odsłonięte miejsce”), od którego bierze początek, według H. Lewy'ego, nazwa greckiego miasta Marathon ${ }^{3}$.

Od drugiego z rdzeni, 'rh (czasownik 'rh znaczy „odsłonić”), pochodzą trzy hebrajskie rzeczowniki używane na określenie ,nagości” fizycznej i metaforycznej: 'erwâ (pięćdziesiąt dwa wystąpienia w Biblii), 'eryâ (sześć wystąpień) oraz ma'ar (dwa wystapienia).

\section{Slownictwo greckie}

W Biblii Greckiej ${ }^{4}$ występują cztery określenia związane z nagością:

\section{a. gymnos}

Odpowiednikiem hebrajskich przymiotników 'êrōm i 'ârôm jest grecki termin gymnos. W Septuagincie i pismach Nowego Testamentu jest on łącznie użyty czterdzieści dziewięć razy, i to zarówno w sensie literalnym, jak i przenośnym ${ }^{5}$. W tym pierwszym oznacza:

- „w pełni nagi”, „,goły”, „obnażony”, „całkowicie rozebrany” (np. Rdz 2, 25; 3, 7; Hi 1, 21; Ez 23, 29; Mk 14, 52; Ap 17, 16);

- „ubrany niewłaściwie” lub „źle”, „poodzierany” (np. Hi 22, 6; 24, 10; Mt 25, 36.38.43-44; Dz 19, 16; Jk 2, 15);

- „bez wierzchniej odzieży”, „częściowo rozebrany”, „w samej bieliźnie” (np. 1 Sm 19, 24; Iz 20, 2; Mi 1, 8; J 21,7).

- „pozbawiony ciała” (o duszy odłączonej od ciała, które spełnia dla niej rolę „odzieży”; 2 Kor 5, 3).

W sensie metaforycznym przymiotnik gymnos oznacza:

• „odsłonięty”, „nieukryty”, „oczywisty” (np. Hi 26, 6; Hbr 4, 13);

- „zwyczajny” (np. 1 Kor 15, 37);

• „nieprzygotowany” (np. Ap 3, 17; 16, 15).

Obok formy przymiotnikowej w Biblii Greckiej występują jeszcze rzeczowniki i czasownik.

\section{b. gymnotes}

Rzeczownik gymnotes występuje w Biblii cztery razy i zawsze dotyczy nagości w sensie przenośnym, jako „niedostatku odzienia” (Pwt 28, 48; Rz 8, 35; 2 Kor 11, 27) albo „braku przygotowania” (Ap 3, 18).

\footnotetext{
${ }^{3}$ Por. H. L e w y: Die semitischen Fremdwörter im Griechischen. Berlin 1895 s. 144.

${ }^{4}$ W Septuagincie i w Nowym Testamencie.

${ }^{5}$ Por. Theological dictionary of the New Testament. Ed. by G. K i t t e 1. Vol. 1. Grand Rapids, Mi 1981 s. 773-774.
} 


\section{c. gymnazō}

Grecy, począwszy od Ajschylosa, używali czasownika gymnazō na określenie ćwiczeń gimnastycznych wykonywanych nago ${ }^{6}$. Z czasem termin ten nabrał znaczenia bardziej ogólnego: „szkolić”, „trenować”, „praktykować” albo „ćwiczyć". Słowo to występuje w Biblii pięciokrotnie, zawsze w sensie wypracowanym przez hellenizm (,ćwiczyć intensywnie ciało i umysł"; 2 Mch 10, 15; 1 Tm 4, 7; $\operatorname{Hbr} 5,14 ; 12,11)$, niekiedy również z domieszką sarkazmu (2 P 2, 14).

\section{d. gymnasia}

Ostatnim biblijnym określeniem wiążącym się z nagością jest rzeczownik gymnasia, oznaczający uprawianie gimnastyki w palestrze przy całkowicie obnażonym ciele, a szerzej - wszelkie ćwiczenia cielesne, często powiązane z rezygnacją $\mathrm{z}$ małżeństwa i niektórych pokarmów. W takim sensie słowo gymnasia zachodzi w Biblii tylko jeden raz, u Pawła (1 Tm 4, 8; por. 4 Mch 11, 20).

Szerokie pole semantyczne powyższych określeń, a także spora ilość tekstów biblijnych sprawiają, iż problematyka nagości na kartach Pisma Świętego stanowi bardzo rozległe. zagadnienie. W niniejszym opracowaniu zostaną przeanalizowane tylko najważniejsze miejsca.

\section{Nagość w sensie dosłownym}

\section{Nagość pierwszych ludzi przed upadkiem}

Wzmianka o nagości człowieka pojawia się po raz pierwszy na kartach Biblii w kontekście wydarzeń w ogrodzie Eden, opisanych na początku Księgi Rodzaju. Pierwsze rozdziały Genesis mają, ze względu na zawarte w nich objawienie, wyjątkowy charakter: są tu odsłaniane nie tyle pradzieje człowieka (w sensie historycznym), ile raczej fundamentalne prawdy dotyczące jego istoty i egzystencji.

Wśród tych elementów pierwotnego doświadczania człowieczeństwa znajduje się też jego cielesność, kobieca i męska. Przy tej okazji natchniony autor przekazuje też niezwykle frapujące spostrzeżenie:

Chociaż mężczyzna i jego żona byli nadzy, nie odczuwali wobec siebie wstydu $(\operatorname{Rdz} 2,25)$.

\footnotetext{
${ }^{6}$ Por. Stownik grecko-polski. Red. Z. A b r a m o w i c z ó w n a. T. 1. Warszawa 1958 s. 484.
} 
Jan Paweł II zauważa, iż nie był to ani brak wstydu, ani jego niedorozwój, ale nie-obecność ${ }^{7}$. W sytuacji pierwotnego doświadczenia człowieka wstyd jeszcze nie zaistniał, jeszcze się nie pojawił, jeszcze nie dał o sobie znać. Jak można wytłumaczyć ową pierwotną sytuację nagości mężczyzny i kobiety przy jednoczesnej nie-obecności wstydu?

Dla człowieka obciążonego grzechem pierworodnym jest to niezwykle trudne. Doświadczenie Adama i Ewy można zrozumieć jedynie w kontekście ich pierwotnej harmonii ze Stwórcą i płynącej z niej pierwotnej niewinności, również niewinności wzajemnego poznania. Dzięki niej mogli patrzeć na siebie i poznawać się w sposób całościowy, integralny i w pełni prawdy o sobie. We wzajemnej komunikacji ich ciała nie były tylko widzialną materią, ale wyrażały ich własne najgłębsze ,ja”, dlatego afirmowali swoją cielesność, widzieli w niej syntezę piękna całego stworzenia i nie odczuwali wobec siebie wstydu. Można tutaj mówić o jakiejś szczególnej »absorpcji wstydu przez mitość«, a jest to mitość Boga samego. Ta milość pozwalała im z cała prostota i niewinnościa obcować ze sobq i cieszyć sie soba wzajemnie jako darem $^{8}$; w ich wzajemnej relacji nie było miejsca na żadną nieuporządkowaną namiętność 9 .

Pierwotne znaczenie nagości wiąże się nierozerwalnie z niewinnością, prostotą i pełnią prawdy. W ich perspektywie ujawnia się »czysta wartość człowieka jako mężczyzny i kobiety, czysta wartość ciała i ptci ${ }^{10}$, a nagość przynależy jakby do istoty człowieka. Niestety, w prapoczątkach dziejów człowieka doszło do dramatycznego pęknięcia.

\section{Nagość po grzechu pierworodnym}

Autor natchniony wyraźnie wskazuje na zmianę w doświadczaniu nagości po grzechu pierworodnym. Początkowo mężczyzna i jego żona byli nadzy $i$ nie odczuwali wobec siebie wstydu $(\mathrm{Rdz} 2,25)$, a po dramatycznym nieposłuszeństwie Bogu otworzyly się im obojgu oczy i poznali, że sq nadzy (Rdz 3, 7). Na czym $\mathrm{w}$ istocie polegała zmiana $\mathrm{w}$ przeżywaniu nagości przez mężczyznę i kobietę, skoro byli nadzy zarówno przed upadkiem grzechowym, jak też i po nim? Na pewnego rodzaju skażeniu umysłu, w skutek czego zepsuło się ich patrzenie na otaczającą rzeczywistość: nastąpiła $\mathrm{w}$ nich projekcja zła na to, co w istocie było czyste i niewinne (por. Tt 1,15 ). A ponieważ doświadczenie to miało charakter pierwotny, stało się ono udziałem każdej istoty ludzkiej.

\footnotetext{
${ }^{7}$ Por. J a n P a w eł I I: Mężczyznq i kobieta stworzyt ich. Lublin 1981 s. 48.

${ }^{8}$ Por. J a n P aw e 1 I I: Medytacja (...) na temat »bezinteresownego daru«. „L'Osservatore Romano". Wydanie polskie. R. 28: 2007 nr 3 s. 42.

${ }^{9}$ Por. S. Ł a c h: Księga Rodzaju. Poznań 1962 s. 213.

${ }^{10}$ Por. J a n P a w e 1 I I: Mężczyznq $i$ kobietq, dz. cyt., s. 50.
} 
Od tej chwili człowiek, naturalnie nakierowany na dobro, stał się zdolny sięgać również po zło. W tej nowej sytuacji zaczął on doświadczać jeszcze jednego obdarowania ze strony swego Stwórcy - sumienia, stojącego na straży jego ładu wewnętrznego. W tym konkretnym przypadku przybrało ono postać wstydu:

[...] spletli gałazki figowe $i$ zrobili sobie przepaski [...] skryli sie przed Panem Bogiem wśród drzew ogrodu [...] »przestraszytem się, bo jestem nagi i ukrylem się» (Rdz 3, 7.10).

Wstyd, wyrażający się w ukrywaniu własnej nagości, należy do tych pierwotnych i podstawowych doświadczeń człowieka, które zostały mu podarowane ku obronie własnej godności, ponieważ budując szczególny mur między nim a drugą osobą, pomaga ustanawiać właściwe relacje międzyosobowe.

Analizując sens pierwotnej nagości należy jeszcze zwrócić uwagę na inny fakt. Nie tylko Adam i Ewa okryli swoje ciało przepaskami z liści figowca, ale uczynił to również sam Stwórca:

Pan Bóg sporzqdził dla mężczyzny i dla jego żony odzienie ze skór i przyodziat ich $(\mathrm{Rdz} 3,21)$.

Z perspektywy Boga ciało ludzkie po grzechu pierworodnym nadal jest piękne ${ }^{11}$, a nagość - w dalszym ciagu wielkim dobrem, teraz jednakże już wyraźnie ukrytym. Grzech zmienił znaczenie pierwotnej nagości, ponieważ zmienił również poczucie sensu ludzkiego ciała, które zaczęło odtąd pożądać tego, co złe, co wabiło oko człowieka i pochlebiało jego dążeniom do wielkości ${ }^{12}$. Nagość nie wyrażała już niewinności człowieka, ale rodziła lęk (przestraszyłem się) i zaczęła potrzebować obrońcy w postaci wstydu (spletli gałazki).

Warto dodać, iż tradycja żydowska przekazała w Targumie Pseudo-Jonatana, datowanym na ok. II-VII wiek po Chr., inną lekcję wersetu Rdz 2, 25. Istotne dla prowadzonych tu analiz słowo "rvmym masoreci zwokalizowali jako "rûmmîm (,nadzy”), natomiast redaktor Pseudo-Jonatana jako “ărûmîm (,mądrzy”, od hebr. 'árûm). Polski przekład tego tekstu brzmi teraz następująco:

A byli oboje madrzy, człowiek $i$ żona jego, toteż nie hańbili się $e^{13}$.

Z perspektywy judaistycznej nagość należy do kategorii mądrości. Jeśli człowiekowi jej brakuje, nagość staje się jego oskarżycielem i wrogiem ${ }^{14}$.

${ }^{11}$ Wspaniałe biblijne opisy piękna ciała ludzkiego znajdują się w Księdze Pieśni nad Pieśniami; są to de facto zachwyty nad pięknem stworzenia i obrazem Boga, jaki nosi w sobie człowiek.

${ }^{12}$ Por. $Ł$ a c h, dz. cyt., s. 216.

${ }^{13}$ Por. J. S u low s k i: Czy Adam i Ewa »byli nadzy«. Łódź 1998 s. 210. 


\section{Nagość w Izraelu}

Na początku XX wieku zrodził się w Niemczech ruch naturystyczny, polegający na praktykowaniu wspólnej nagości na świeżym powietrzu. Zdobył on szybko wielu zwolenników, a nawet przybrał formę naturyzmu chrześcijańskiego. Jego zwolennicy odwołują się między innymi do Biblii Starego Testamentu, do tekstów o nagości Adama i Ewy czy o prorokujących nago Saulu (1 Sm 19, 24) i Izajaszu (Iz 20, 2).

Tymczasem Izraelici przestrzegali bardzo restryktywnie nakazu Jahwe, aby osłaniać ciało odzieżą, a nagość tolerowali jedynie podczas zbliżenia płciowego. Dobrą ilustracją może być idiom hebrajski: „odsłonić czyjąś nagość”, oznaczający: „mieć z kimś stosunek seksualny” (por. Kpł 18; 20).

Innym przykładem starotestamentowego spojrzenia na nagość jest historia Noego. Kiedyś ów patriarcha upił się winem, a potem położył się nago w swoim namiocie i zasnął. W takim stanie miał nieszczęście zobaczyć go jego syn Cham. Został on za to nie tylko skarcony, ale nadto obłożony klątwa, natomiast jego bracia, którzy przykryli ojca wchodząc do namiotu tyłem, aby nie widzieć jego nagości, otrzymali błogosławieństwo (Rdz 9, 20-27).

Znamienne w omawianej kwestii są teksty dotyczące kultu starotestamentowego. Bóg powiedział do Mojżesza:

Nie będziesz wstępowat po stopniach do mojego ottarza, żeby się nie odkryta nagość twoja (Wj 20, 26).

Zakaz ten miał eliminować możliwość zobaczenia przez zgromadzonych Izraelitów intymnych części ciała kapłana, odzianego jedynie w tunikę na gołym ciele. Temu samemu celowi służył nakaz noszenia przez kapłanów pod tuniką krótkich lnianych spodni (Wj 28, 42). Kult izraelski, w przeciwieństwie, do praktyk pogańskich, nie tolerował bowiem żadnych form nagości.

Podejście Narodu Wybranego do nagości ciała było jednoznaczne. Skoro Bóg na początku zasłonił ciało upadłego człowieka odzieniem, aby w ten sposób uczynić je niewidocznym dla innych, Izraelici nie mogli postępować inaczej. Stąd uważali za niewłaściwe, hańbiące i upokarzające:

- obnażać swoje ciało przed innymi (por. Iz 47, 3);

- obnażać ciała innych osób (por. Kpł 18, 6-18);

\footnotetext{
${ }^{14}$ Por. J. C h m i e l: Nuditas sacra. „Alma Mater”. R. 2002 nr 38.
} 
- przyglądać się nagości innych (por. Rdz 9, 20-27); za wyjątkową nikczemność uważali pozbawienie kogoś świadomości przez upicie go, aby popatrzeć na jego nagość (Ha 2,15).

\section{Nagość w pismach Nowego Testamentu}

Wymagania moralne Nowego Testamentu idą jeszcze dalej. Ilustracją może być szczegół o odzieniu apostoła Piotra w galilejskiej tradycji o zmartwychwstaniu Chrystusa, zapisany w Ewangelii według św. Jana:

Szymon Piotr [...] przywdziat na siebie wierzchniq szate - byt bowiem prawie nagi - i rzucil się wptaw do jeziora $(\mathrm{J} 21,7)$.

W tekście greckim nie ma wyrażenia „prawie nagi”, ale „nagi” (gymnos). Powiedziano wcześniej, iż Izraelici nie mieli zwyczaju obnażania swoich ciał. Można zatem się domyślać, że Piotr zdjął do pracy na łodzi tunikę i pozostał w samej bieliźnie, co w języku greckim wyraża się również określeniem gymnos. Apostoł uznał jednak taki strój za nieodpowiedni na spotkanie ze Zmartwychwstałym. Przywdział w pośpiechu tunikę, mimo iż za chwilę miał ją całkowicie zmoczyć.

Apostoł Paweł, pisząc w Liście do Rzymian o upadku człowieka, wylicza różne grzechy, a wśród nich bezczeszczenie (atimē) własnych ciat (Rz 1, 24). Takie sformułowanie sugeruje, iż ciało człowieka posiada własną godność i dlatego zasługuje na szacunek. Kiedy człowiek traktuje je niewłaściwie, na przykład obnosząc się ze swoją nagością, może go tego szacunku (timē) pozbawić.

Porównując Kościół do ludzkiego ciała, Paweł pisze o rozmaitych częściach organizmu człowieka:

[...] troszczymy się o przyzwoitość wstydliwych czlonków ciała, gdyż wobec tych, które nie należa do wstydliwych, nie istnieje taka potrzeba (1 Kor 12, 23-24).

Apostoł wyraźnie nazywa niektóre członki ciała wstydliwymi, to znaczy wymagającymi szczególnej delikatności, szacunku i dyskrecji. Jest znamienne, iż są to organy związane z ludzką rozrodczością. Wobec nich jest zalecana szczególna przyzwoitość.

Jakkolwiek nagość nie wiąże się z seksualnością w sposób bezpośredni, Paweł uczy, iż sfera seksualna człowieka powinna być dostępna tylko dla jego współmałżonka, a to oznacza, iż nagość musi być zasłonięta przed oczami obcych (1 Kor 7, 2-4). Jest znamienne, iż nagość eksponowaną dla osób postronnych autorzy natchnieni wiążą z działaniem sił demonicznych: 
[...] wybiegt Mu naprzeciw pewien czlowiek z miasta, opętany przez złe duchy. Już od dtuższego czasu nie nosit ubrania, i mieszkat nie $w$ domach, lecz $w$ grobach $(Ł \mathrm{k} 8,27)$.

Opętany postępował dokładnie odwrotnie niż przewidywało Prawo Mojżeszowe.

\section{Nagość w sensie przenośnym}

Autorzy natchnieni posługiwali się pojęciem nagości nie tylko w sensie dosłownym, ale także metaforycznym. Oto kilka przykładów.

\section{Dla Boga wszystko jest nagie, czyli jawne}

Hagiografowie posługiwali się ideą nagości, kiedy pouczali, że Bóg jest wszechwiedzący i że nic nie jest dla Niego zasłonięte i ukryte.

Szeol dla Niego jest nagi ( 'ārôm; Hi 26, 6).

Tymi słowami Hiob objaśnia swojemu rozmówcy, iż władza Boga rozciaga się nie tylko nad tym światem, ale także nad zaświatami. Kraina umarłych, czyli Szeol jest dla Niego naga, to znaczy nie kryje przed Nim żadnych tajemnic i całkowicie podlega Jego rozkazom.

Podobną myśl przekazał autor Listu do Hebrajczyków:

Nie ma stworzenia, które by dla Niego byto niewidzialne; przeciwnie, wszystko odkryte (gymnos) jest $i$ odstonięte (tetrachēlismenos) przed oczami Tego, któremu musimy zdać rachunek $(\mathrm{Hbr} 4,13)$.

W perykopie, z które pochodzą powyższe słowa, hagiograf uroczyście poucza, iż niewiara zawsze będzie zdemaskowana bądź przez słowo Boże (Hbr 4, 12), bądź przez samego Boga. Nic Mu nie umknie, gdyż jest wszechwiedzący i wszystko jest dla Niego nagie, czyli jawne i znane.

\section{Nagość jako symbol niedostatku}

W skrajnym przypadku nagość może być spowodowana brakiem odzieży. Dlatego w Biblii symbolizuje ona również nędzę, ubóstwo i niedostatek. W Starym Przymierzu Jahwe zapowiada, że ukarze występki Izraela głodem, pragnieniem i nagościq ('êrōm; Pwt 28, 48), czyli brakiem podstawowych artykułów.

W takim samym znaczeniu Paweł posłużył się dwukrotnie terminem „nagość”, gdy pisał: 
- o więzi z Chrystusem, której nie są w stanie osłabić utrapienie, ucisk, prześladowanie, głód i nagość... (gymnotēs; Rz 8, 35);

- o swojej ofiarnej służbie dla Chrystusa $w$ glodzie i pragnieniu, w licznych postach, $w$ zimnie i nagości (gymnotēs; 2 Kor 11,27).

Jezus zapowiada, iż każde zaradzenie niedostatkowi (gymnos) na ziemi zostanie nagrodzone na sądzie Bożym, natomiast brak skutecznej pomocy potrzebującym stanie się powodem oskarżenia:

[...] bytem nagi (gymnos), a przyodzialiście Mnie [...] kiedy widzieliśmy Cię nagim (gymnos)? [...] bylem nagi (gymnos), a nie przyodzialiście Mnie [...] kiedy widzieliśmy Cię nagim (gymnos)? (Mt 25, 36.38.43.44).

\section{Nagość jako nieprzygotowanie serca}

Jeszcze inny sens przenośny nadał pojęciu nagości redaktor Księgi Apokalipsy. W Liście do Laodycei nazywa nagim człowieka nieprzygotowanego do królestwa Bożego:

[...] mówisz: »Jestem bogaty« $i$ »wzbogacilem się«, i niczego mi nie potrzeba", a nie wiesz, że to ty jesteś nieszczęsny i godzien litości, i biedny, $i$ ślepy, i nagi (gymnos; Ap 3, 17).

Przedstawia mu też konkretne propozycje, jak przykryć nagość (gymnotēs; Ap 3, 18), czyli jak podjąć dzieło współpracy z Chrystusem.

Przeprowadzone dotą analizy upoważniają do stwierdzenia, iż człowiek Biblii miał bardzo jednoznaczny stosunek do nagości. Widział w nim wielki dar Boga, który domaga się wyjątkowego szacunku, dyskrecji i ukrycia. Na straży tego daru stoi sumienie, które broni człowieka uczuciami lęku i wstydu przed sobą samym i innymi ludźmi. Gdy sumienie zostanie zagłuszone, ciało człowieka doznaje odarcia z należnej mu czci. Nagość jest bowiem wartością, którą rządzą - jak uczył Jan Paweł II - nie tylko estetyka, ale przede wszystkim etyka ${ }^{15}$.

\section{Nagi młodzieniec z Ewangelii Markowej}

Ostatnia część niniejszego opracowania będzie dotyczyła Markowej wzmianki o nagim młodzieńcu i próby jej interpretacji w świetle tego, co dotąd powiedziano na temat biblijnej nagości. Ewangelista umieścił ów epizod zaraz po aresztowaniu Jezusa w Ogrodzie Oliwnym, gdy uczniowie opuścili Go i uciekli, a tłum ruszył z Aresztowanym w kierunku pałacu arcykapłana.

\footnotetext{
${ }^{15}$ Por. tamże.
} 
A pewien młodzieniec szedt za Nim, odziany prześcieradtem na gotym ciele. Chcieli go chwycić, lecz on zostawit prześcieradto i uciekt »od nich" nago (Mk 14, 51-52).

Pierwszym etapem pracy nad tym tekstem będzie próba zidentyfikowania owego młodego człowieka, a kolejnym - wskazanie możliwych sensów jego nagości.

\section{Kim byl „pewien młodzieniec”?}

(1) Wielu komentatorów upatruje w neaniskos tis (,pewien młodzieniec”) samego Marka ewangelistę. Taka hipoteza harmonizuje ze wzmianką Łukasza, iż w Jerozolimie znajdował się dom Marii, matki Jana, zwanego Markiem, gdzie zbierali się chrześcijanie jerozolimscy na modlitwę (Dz 12, 12-17). Tam też mogła mieć miejsce Ostatnia Wieczerza. Po jej zakończeniu zasypiający już syn gospodyni, Marek, zobaczywszy ludzi, którzy wyruszyli aresztować Jezusa, albo też dowiedziawszy się o zdradzie Judasza, narzucił na siebie prześcieradło i pobiegł do Ogrodu, aby uprzedzić Nauczyciela przed niebezpieczeństwem. Przybył jednak za późno i omal nie wpadł w ręce straży. Pochwycony, wymknął się im zostawiając $\mathrm{w}$ ich rękach prześcieradło ${ }^{16}$.

Komentatorzy sądzą, że przeżycia tamtej nocy tak mocno wpisały się w pamięć Marka, że redagując Ewangelię, zamieścił w niej swój mały anonimowy autoportret. Natomiast przeciwnicy tej tezy powołują się na świadectwo Papiasza, biskupa Hierapolis, przekazane w IV wieku przez Euzebiusza z Cezarei, iż Marek nigdy osobiście nie spotkał Jezusa: [Jan] Marek ani Pana nie styszat, ani nie należat do Jego grona, i tylko później byt towarzyszem Piotra ${ }^{17}$. Powołują się nadto na motyw psychologiczny i twierdzą, iż Marek nie odważyłby się dołączyć do narracji o męce Pańskiej epizodu bądź co bądź komicznego na swój temat ${ }^{18}$. Musiałby przecież liczyć się z faktem, że czytelnicy i słuchacze jego dzieła będą go pytać, kim jest w rzeczywistości ów młodzieniec. A wówczas Marek musiałby im przyznawać, że to jest on sam.

(2) Inni bibliści podzielają opinie pisarzy wczesnochrześcijańskich i identyfikują pewnego młodzieńca $\mathrm{z}$ innymi osobami $\mathrm{z}$ otoczenia Jezusa:

- $\mathrm{z}$ apostołem Janem (Beda Czcigodny, Jan Chryzostom, Grzegorz Wielki, Piotr Chryzolog);

\footnotetext{
${ }^{16}$ Por. J. C h m i e l: Trudności interpretacyjne Mk 14, 51-52. W: Pieśniami dla mnie Twoje przykazania. Red. W. C h r o s t o w s k i. Warszawa 2003 s. 90-91.

${ }^{17}$ Zob. Eu ze bi us z z Ce zare i: Historia ecclesiastica $3,39,15$.

${ }^{18}$ Por. S. H a t $\mathrm{t}$ o n: Mark's naked disciple. The semiotics and comedy of following. „Neotestamentica". Vol. 35: 2001 no 1-2 s. 35-48.
} 
- $\mathrm{z}$ apostołem Jakubem Młodszym (Epifaniusz, Hieronim);

- z Łazarzem z Betanii, Piotrem albo Pawłem;

- $\mathrm{z}$ anonimowym młodzieńcem, który opowiedział swoją historię Piotrowi lub jego sekretarzowi Markowi (por. Mk 10, 17-22) ${ }^{19}$.

(3) Jeszcze inni widzą w tym epizodzie wpływy typologiczne tekstów Starego Testamentu, na przykład:

- Rdz 39, 12, gdzie Józef zostawia swój płaszcz w rękach żony Potifara i ucieka;

- Am 2, 16, gdzie bohaterowie uciekają nago;

- Iz 40, 30, gdzie młodzieńcy tracą siłę

(4) Ciekawe rozwiązanie proponuje J. Walsh ${ }^{21}$. Według niego był to Marek, sekretarz Piotra. W chwili redakcji drugiej Ewangelii (około 60 roku po Chr.) mógł mieć mniej więcej czterdzieści lat lub nieco więcej. A zatem w czasie pamiętnej nocy w Jerozolimie był chłopcem dziesięcio-, dwunastoletnim, zaś świadkiem jego „wyczynu” był Piotr. Wspominał on słuchaczom w ustnych katechezach o tym wydarzeniu, a kiedy po latach Marek zaczął spisywać jego pouczenia i zamierzał ten fragment - jako nie mający nic wspólnego z Jezusem opuścić, apostoł zadecydował, aby go utrwalić.

Żadna z przedstawionych wyżej hipotez nie jest do końca przekonująca. Ani sam autor Ewangelii, który wprowadził nagiego młodzieńca do swego dzieła nieoczekiwanie i już nigdy więcej o nim nie wspomina, nie zidentyfikował go, ani nie uczynili tego inni pisarze natchnieni ${ }^{22}$. Nie da się zatem ustalić tożsamości tej postaci w sposób pewny.

\section{Nagość „pewnego młodzieńca"}

W analizowanym tekście ewangelista odniósł się do nagości młodzieńca dwukrotnie:

- Mk 14, 51: młodzieniec idący za Jezusem odziany byt prześcieradtem na gotym ciele (peribeblēmenos sindona epi gymnou);

${ }^{19}$ Por. C h m i e l: Trudności, dz. cyt., s. 91.

${ }^{20}$ Por. Tamże, s. 91-92.

${ }^{21}$ Por. J. W a 1 s h: The two linen cloths. Position Paper 2006 no 389 s. 157-161.

${ }^{22}$ Znamienny jest fakt, iż M a te u s z i Łukas z, którzy korzystali w swoich dziełach z tekstu Markowego, opuścili passus o nagim młodzieńcu. R. B u $1 \mathrm{t}$ m a n n uważa, iż uczynili tak, ponieważ go nie rozumieli (R. B u $1 \mathrm{t} \mathrm{m}$ a n n: The history of the synoptic tradition. Oxford $1963 \mathrm{~s}$. 269), inni komentatorzy sądzą, iż ewangeliści uważali go za zbędny, a jeszcze inni twierdza, że tego passusu nie było w recenzji M a r k a, z której synoptycy korzystali. 
- Mk 14, 52: podczas próby ujęcia zostawit on prześcieradto i uciekt »od nich« nago (gymnos ephygen).

W pierwszym wersecie autor posłużył się wyrażeniem: peribeblēmenos sindona. Imiesłów peribeblemmenos („otoczony”, „owinięty”) wskazuje, iż lniane płótno (sindōn) nie było jedynie przerzucone w pośpiechu przez ciało młodzieńca, ale szczelnie je owijało. Natomiast kolejny zwrot: epi gymnou (,na gołym”) jest nieco dziwny, ponieważ brakuje w nim rzeczownika soma („,iało”). Jego funkcje pełni przymiotnik gymnos (,nagi”); a zatem zwrot epi gymnou (,na nagości”) należy tłumaczyć: „na gołej skórze”. Uwagę ewangelisty na temat stroju młodzieńca należy więc rozumieć następująco: był on starannie ubrany w jakąś lnianą płachtę, ale pod spodem nie miał nic.

W drugim z wersetów ewangelista zanotował, iż młodzieniec, pozostawiwszy prześcieradło, uciekł gymnos (,nagi”). Skoro płótno spoczywało epi gymnou (,na jego gołej skórze”), musiał więc uciec od thumu nago, nie zaś, jak sugerują niektórzy komentatorzy, „w spodniej bieliźnie” (por. J 21, 7 ) 23 .

\section{Dalsze cechy tekstu Mk 14, 51-52}

Przy bardziej wnikliwym spojrzeniu można zauważyć w badanym passusie jeszcze inne swoistości. Pomocny w tym może okazać się przekład interlinearny Mk 14, 51-52:

„I młodzieniec jakiś wspóttowarzyszył mu, odziany prześcieradłem na nagim, i chwytają go. On zaś zostawiwszy prześcieradło nagi uciekł”24.

- Znamienne i zapewne zamierzone przez autora jest dwukrotne użycie przymiotnika gymnos. Marek mógłby łatwo uniknąć powtórzenia zastępując na przykład zwrot „odziany prześcieradłem na nagim” wyrażeniem „nie mając na sobie nic prócz prześcieradła”. Prawdopodobnie hagiografowi zależało jednak na repetycji słowa.

- Powtórzenie dotyczy też rzeczownika sindōn („prześcieradło”, „płótno”). Jego użycie w wersecie Mk 14, 52 jest wręcz nieeleganckie; czytelnik spodziewałby się w tym miejscu zaimka rzeczownikowego: „On zaś zostawiwszy je nagi uciekł". Można odnieść wrażenie, że hagiograf zamierzał skupić uwagę czytelnika właśnie na prześcieradle.

\footnotetext{
${ }^{23}$ Por. C. E v a n s: Mark 8:27-16:22. Nashville, Tn 2001 s. 428.

${ }^{24}$ Zob. Grecko-polski Nowy Testament. Wydanie interlinearne. Tłum. R. P o p o w s k i. Warszawa 1995 s. 224.
} 
- Pewna sugestia autora kryje się też zapewne w wyrażeniu „młodzieniec jakiś współtowarzyszył mu". Wydaje się, iż właściwsze w tym miejscu byłoby sformułowanie: „młodzieniec jakiś współtowarzyszył tłumowi”, ponieważ w thumie znajdował się i Jezus. Ewangelista podkreślił jednak, iż młody człowiek postępował za Jezusem.

\section{Możliwe interpretacje narracji o nagim młodzieńcu}

Te dwa krótkie wersety Markowe wywołują wiele kontrowersji wśród egzegetów. Sam młodzieniec pozostaje ostatecznie postacią niezidentyfikowaną, a jego nagość - w świetle tego, co powiedziano poprzednio - można rozumieć wieloznacznie. Skoro Izraelici unikali nagości i nigdy nie obnażali się publicznie, być może nagość młodzieńca ma wymowę przenośną i wskazuje albo na nieprzygotowanie serca, albo też na ogołocenie, niedostatek i ubóstwo.

$\mathrm{Z}$ całą pewnością epizod o nagim młodzieńcu nie znalazł się w drugiej Ewangelii kanonicznej przypadkowo, lecz stanowi ważny element jej konstrukcji, zwłaszcza Ewangelii męki, śmierci i zmartwychwstania Chrystusa. Zapewne też pierwszoplanowym aspektem tej narracji nie jest zwyczajna historia, ale symbolika i teologia.

Poniżej przedstawiono różne możliwości interpretacji tego tekstu z uwzględnieniem jego wymowy teologicznej.

- H. Jackson uważa, iż tekst o nagim młodzieńcu należy odczytywać w powiązaniu z perykopą o ślepym Bartymeuszu, który słysząc, iż drogą przechodzi Jezus, błagał Go o pomoc, a przywołany zrzucit z siebie płaszcz, zerwat się na nogi i przyszedt do Jezusa [...] Natychmiast przejrzat i szedt za Nim droga (Mk 10, 46-52). Analizowane wersety o nagim młodzieńcu stają się bardziej zrozumiałe $\mathrm{w}$ świetle tego opowiadania o ślepcu, ponieważ obie narracje mają charakter paralelnych, aczkolwiek kontrastowych, typologii. Bartymeusz odziany w płaszcz, symbol „starego człowieka”, odrzuca go i podąża za Jezusem. Podobnie sprawa ma się z młodzieńcem. On też jest początkowo nieprzygotowany do królestwa Bożego (symbolizuje to jego nagość przykryta prześcieradłem ,starego człowieka"). Odrzuca je, ale zamiast pójść za Jezusem, ostatecznie ucieka (oddala się) od Niego ${ }^{25}$.

Perykopa o nagim młodzieńcu ma charakter parenetyczny i ukazuje ikonę prawdziwego ucznia Chrystusa: za Panem może podążyć jedynie ten, kto obna-

\footnotetext{
${ }^{25}$ Por. H. J a c k s o n: Why the youth shed his cloak and fled naked. The meaning and purpose of Mark 14:51-52. „Journal of Biblical Literature”. Vol. 116: 1997 no 2 (Summer) s. 287289.
} 
żył się ze „dawnego człowieka”26; tak rozumiana „nagość” jest nieodzowna na drodze wiary.

- M. Cosby sądzi, iż narracja o nagim młodzieńcu wyraźnie przynależy do struktury Ewangelii Markowej. Natchniony autor odsłania w swoim dziele, począwszy od perykopy Mk 8, 27-38, narastający rozdźwięk w spojrzeniu Jezusa i Dwunastu na problematykę mesjanizmu i uczniostwa: apostołowie oczekują od Jezusa mesjańskiej pomyślności i wystawności, gdy tymczasem On uczy ich o służbie i cierpieniu Mesjasza. Ta kontrowersja osiaga swój symboliczny i wymowny klimaks w ucieczce młodzieńca od Jezusa, będącej symbolem przegranej oczekiwań i marzeń uczniów. W osobie tego młodego człowieka apostołowie uciekają od Jezusa, nie biorą krzyża i nie naśladują Go. Dopiero kiedy spotkają się ponownie w Galilei już po zmartwychwstaniu, wszystko się odmieni ${ }^{27}$.

- E. Schnellbächer uważa, iż młodego człowieka z Mk 14, 51-52 należy łączyć z młodzieńcem z Mk 16, 5-7:

[Kobiety] weszly do grobu i ujrzaly mlodzieńca, siedzqcego po prawej stronie, ubranego w biata szate; i bardzo sie przestraszyly.

Jest znamienne, iż Marek określa zarówno anioła, jak i nagiego człowieka terminem neaniskos („,młodzieniec”); w obu przypadkach wspomina też jego odzież. Takie zestawienie dwóch młodzieńców pozwala wysnuć teologiczny wniosek, że człowiek odarty ze wszystkiego, zostaje przywrócony do chwały za sprawą męki i zmartwychwstania Chrystusa ${ }^{28}$.

- J. Walsh zestawia ze sobą dwa puste płótna, prześcieradło nagiego młodzieńca i całun grobowy Jezusa (Mk 15, 46). Ewangelista używa na określenie obu „szat” tego samego terminu sindōn. Obecność dwóch płócien w Ewangelii męki pozwala na wyciągnięcie wniosku, iż skoro pusty całun był wymownym świadkiem zmartwychwstania Jezusa, zatem puste prześcieradło młodzieńca stało się nieoczekiwanie zapowiedzią tego wydarzenia. Naocznym świadkiem obu całunów był apostoł Piotr ${ }^{29}$.

- Zdaniem C. Martiniego druga Ewangelia kanoniczna powstała jako podręcznik dla katechumenów ${ }^{30}$. Nie dziwi zatem, że H. Fleddermann i F. Kermode

${ }^{26}$ Por. C h m i e l: Trudności, dz. cyt., s. 94.

${ }^{27}$ Por. M. C o s by: Mark 14:51-52 and the problem of gospel narrative. „Perspectives in Religious Studies". Vol. 11: 1984 no 3 (Fall) s. 219-231.

${ }^{28}$ Por. E. S chn e $11 \mathrm{~b}$ ä che r: Das Rätsel des neaniskos bei Markus. „Zeitschrift für die Neutestamentliche Wissenschaft“. Bd. 73: 1982 s. 127-135.

${ }^{29}$ Por. W a 1 s h, dz. cyt., s. 161.

${ }^{30}$ Por. C. M art in i: Litinerario spirituale dei dodici nel Vangelo di Marco. Roma 1987 s. 7. 
widzą w młodzieńcu bez odzienia figurę tych chrześcijan, którzy z powodu prześladowań porzucili wiarę i zaparli się chrztu, do którego przystapili w białej szacie, moga jednak doświadczyć odrodzenia przez powrót do wiary ${ }^{31}$.

- Być może interpretacja tego fragmentu jest znacznie prostsza niż zaproponowane powyżej rozwiązania. Ewangelista zamierzał zapewne podkreślić, iż w czasie, gdy Jezus był przygotowany na prześladowania i niebezpieczeństwa, Jego uczniowie nie byli. Kiedy zgraja z mieczami i kijami przybyła aresztować Jezusa, apostołowie wpadli w panikę i utracili pewność siebie. Jeden $\mathrm{z}$ nich uderzył mieczem stuge najwyższego kapłana, wszyscy Go opuścili i uciekli, a nawet młody człowiek, być może kandydat na ucznia Jezusa, ledwie wymknął się zgrai i również uciekł - w pohańbieniu i dysfamii. W ten sposób wypełniła się w sposób dosłowny zapowiedź Mistrza, że wszyscy odpadną (Mk 14, 27). W przeciwieństwie do nich Jezus trwał niezłomnie, gotów wypić kielich, który podawał $\mathrm{Mu}$ Ojciec $(\mathrm{Mk} \mathrm{14,36)}$.

Choć niektórzy egzegeci (np. J.-M. Lagrange) uważają, iż epizod o nagim młodzieńcu nie ma większego znaczenia dla całości drugiej Ewangelii kanonicznej, powyższe studium nad tekstem Mk 14, 51-52 w świetle biblijnej teologii nagości może prowadzić do zgoła przeciwnych wniosków. Choć są możliwe różne interpretacje tego fragmentu, a żadna $\mathrm{z}$ nich nie może rościć sobie pretensji do wyłączności, wszystkie one poszerzają spojrzenie na Jezusa-Mesjasza, Jego mękę i zmartwychwstanie, a także na Jego apostołów i uczniów.

Bez wątpienia passus ten przekazuje rzeczywistą historię, choć niewątpliwie zinterpretowaną teologicznie. Można więc go określić jako historię pozostającą na usługach teologii. Jeśli uznać przenośne znaczenie nagości w tej perykopie, można ją odnieść przede wszystkim do konieczności ogołocenia się ze wszystkiego, zwłaszcza ze „starego człowieka”, jako warunku pójścia za Jezusem. Jeśli zaś przyjąć nagość w sensie dosłownym, czyli fizycznym, wtedy w każdym odejściu od Chrystusa trzeba widzieć niespodziewane obnażenie - grzech staje się źródłem hańby, wstydu i dysfamii.

${ }^{31}$ Por. H. F l e d d e r m a n n: The flight of a naked young man (Mark 14:51-52). „Catholic Biblical Quarterly”. Vol. 41: 1979 no 3 s. 412-418; F. K e r mod e: The Genesis of secrecy. On the interpretation of narrative. Cambridge, Ma; London 1979 s. 55-64.

${ }^{32}$ Por. E v a n s, dz. cyt., s. 429. 